\title{
Freek Van de Velde
}

\section{Degeneracy: The maintenance of constructional networks}

\section{Introduction}

In this article it is argued that long-term drifts that destroy grammatical strategies a language disposes of in its functional domains are not as detrimental as one might think, thanks to a property that goes under the name of "degeneracy", a technical term from evolutionary biology for the phenomenon that structurally different elements can fulfil the same function. To bring out the diachronic effects of degeneracy, a construction grammar perspective will be taken, with special emphasis to the horizontal relations in constructional networks, which so far have been somewhat neglected in comparison with the vertical relations.

The article is structured as follows: in the remainder of this introduction, I will first introduce the concept of degeneracy, as this is not a familiar notion in linguistics. Second, I will detail what I understand by constructional networks in Construction Grammar. In section 2, I will introduce two cases of constructional networks: Dutch experience predicates and Dutch subordinate clauses. In section 3, I trace the diachrony of these constructional networks, showing how they are degenerately transformed. Section 4 rounds off with the conclusions.

\subsection{Degeneracy}

Like the stock market or ant colonies, language is a complex adaptive system (Holland 1992; Steels 2000; Beckner et al. 2009; Bybee 2010). Such systems display emergent properties that cannot be understood by looking at its individual components alone. One of these properties is what in biology is called "degeneracy". In this context, degeneracy has nothing to do with its common sense meaning of deterioration, but is a technical term for the phenomenon that structurally different elements can fulfil the same function (see Edelman and Gally 2001).

A simple example is thermoregulation in the human body, which is degenerately controlled by (a) perspiration, (b) arteriolar vasodilation, (c) shivering, (d) countercurrent flow, (e) wearing protective clothing, (f) huddling, etc. Degeneracy is related to the notion of redundancy, but one of the differences is that degenerate features may play a role elsewhere in the system as well. To 
stick to the example of thermoregulation in humans, consider the role of walking upright. This plays a role in thermoregulation, as the body catches less solar radiation and catches more wind, thus helping to keep the body cool in warm climates, but one would be hard pressed to maintain that thermoregulation is the sole function of our species' upright posture: it also adds to the expansion of the visual perimeter, and has energetic advantages in locomotion, for instance.

Degeneracy has been applied to biological complex adaptive systems, but hitherto its relevance for language has only been pointed out cursorily (Edelman and Gally 2001: 13764) and has never been studied in depth, despite the growing idea that language change can be modeled by appealing to general evolutionary processes (Croft 2000; Ritt 2004; Mufwene 2008; Rosenbach 2008; Steels 2011a). ${ }^{1}$ In fact, the notion of degeneracy can be readily applied to various phenomena in language. Examples include:

(a) The marking of the plural by both umlaut and a plural suffix in German (e.g. Mann - Männer)

(b) the expression of past tense by ablaut and by a dental suffix (e.g. English spoke vs. talked)

(c) the expression of past time reference both by a prefixed "augment" $e$ - and a suffixed sigmatic marker -s- in Ancient Greek and Old Indic aorists (e.g. Ancient Greek é-lu-s- $a$ 'I unbound')

(d) Syntactic agreement markers (e.g. Gumawana Komu ku-mwela 'you 2SGclimb', see Siewierska 2004: 120-127)

Note that just as in biological degeneracy, there is no pure "redundancy" in these linguistic examples either: with regard to (a), it can be pointed out that both i-umlaut and -er-suffixation play a role elsewhere in the system as well (for deriving causatives and nomina actionis, respectively), with regard to (b) it can be pointed out that there is lexical differentiation between both strategies, and arguably also differences in meaning (see Bolinger 1980; Levin 2009), with regard to (c) it can be pointed out that the $e$-augment is also used in imperfects and the sigmatic infix is also used in the future, and with regard to (d) it can be pointed out that syntactic agreement is not redundant with non-pronominal subjects.

In language as well as in other communication codes, redundancy is beneficial as it offers protection against information loss in cases of signal perturbation. This is well-understood by computer programmers, who are familiar with in-built redundancy in their codes. Degeneracy offers the same "robustness"

1 See also blog posts by Givón (Funknet, 14 Aug. 2011) and Winters (2011, http://replicatedtypo. com/robustness-evolvability-degeneracy-and-stuff-like-that/4026.html). 
advantage, but has an additional advantage of "evolvability" (Whitacre and Bender 2010). Degeneracy increases the possibility of complex adaptive systems to move over the fitness landscape. It is precisely this second advantage that will be focused on in this paper. In form-function change in language, speakers renew their grammar. Degeneracy explains how this comes about without overhauling the semiotic code. A comparison with the example of thermoregulation of the human body can make this clear: many mammals use "horripilation" (or "piloerection"), the process of making one's fur stand on end, as a thermoregulatory process. Humans have lost this ability as a consequence of a long-term general process ("drift") of losing body hair, although a vestigial trait is still present in the form of cutis anserine, or goose bumps. The fact that thermoregulation is degenerate, means that it is robust to the loss of body hair. But there is more: degeneracy in thermoregulation not only increases robustness, but also evolvability, firstly because the hair loss has evolutionary advantages (e.g. in shedding lice, see Pagel 2007), and second because goose bumps are now available for refunctionalisation.

\subsection{Networks in Construction Grammar}

In the last 15 years or so, Construction Grammar has established itself firmly in linguistics. It meshes particularly well with usage-based approaches (see Bybee and Beckner 2010: 842-845), especially in the fields of variational linguistics, diachronic linguistics and language acquisition. Inevitably, the scope of what is understood by Construction Grammar has widened, so that it is nowadays more accurate to speak of Construction Grammars - plural - than of Construction Grammar (see Croft and Cruse 2004).

Some versions of Construction Grammar have added epithets to the name, as for instance Radical Construction Grammar (Croft 2001), Fluid Construction Grammar (Steels 2011b), Embodied Construction Grammar (Bergen and Chang 2013) or Sign-Based Construction Grammar (Michaelis 2009). Not all of these Construction Grammar variants share the same views on the ins and outs of the model, and they disagree on the technical representation. Still, there is a core creed to which most of them subscribe. Language is basically a fund of “constructions", pairings of form and meaning, of varying degrees of complexity, and these constructions form taxonomic networks. The vertical dimension of these networks revolves around the idea of schematicity: the higher positions in the network are occupied by schematic constructions, which hierarchically subsume the lower positions with (partially) specific instantiations of the abstract constructions. Whereas more traditional linguistic approaches have a division 
between syntax and the lexicon, constructional approaches to language generally reject such a division (see e.g. Croft and Cruse 2004: 255-256). In the words of Goldberg (2006: 18): “It's constructions all the way down”. ${ }^{2}$ Indeed, if schematic - that is lexically underspecified - constructions like the ditransitive for instance have their own idiosyncratic meaning that cannot be reduced to its parts (see Goldberg 1995), they do not differ really from individual words, as they realise an irreducible form-function correspondence. The same applies to the level below the word: in Construction Grammar bound morphemes convey meaning in a way not unlike free morphemes (see Booij 2010 in defence of Constructional Morphology; also see Booij and Hüning, this volume). ${ }^{3}$ The various types of constructions can be classified according to the dimension atomiccomplex and the dimension schematic-specific, which are orthogonal to each other. As becomes clear in Table 1, the latter dimension is gradual in nature: partially schematic atomic constructions are bound morphemes and partially schematic complex constructions are multi-word constructions with a mixture of lexically fixed parts and lexically underspecified slots.

Table 1: Different types of constructions

\begin{tabular}{llll}
\hline & Schematic & Partially schematic & Specific \\
\hline Atomic & $\mathrm{N}$ & $-s$ & cat \\
Complex & {$[$ Transitive NP V NP] } & {$[$ [Poss way] PP] } & let alone \\
\hline
\end{tabular}

Constructions of different sizes, from fully lexically instantiated multi-word expressions (e.g. kick the bucket) over partially lexically instantiated constructions like the way-construction (see Goldberg 1996; Israel 1996), over bound morphemes (e.g. the third person verbal ending $-s$ ) to fully lexically underspecified constructions (e.g. the ditransitive construction), form a giant network, and each

2 There is disagreement about whether fully instantiated constructions (also called "constructs") also count as constructions (see Taylor 2004 for a critique; see also Norde, De Clerck, and Colleman, this volume).

3 This is not a new idea, but goes back to at least Bloomfield, and it is one of the foundational principles of the Columbia School of Linguistics, as set out by Diver (Huffman 2001). Van der Horst (1995: 239) interestingly points out that there seems to be an iconic relation between form and meaning such that concrete, lexical meaning is encoded by concrete lexemes, whereas bound morphemes and even less "material", non-segmental signifiants (e.g. word order regularities such as V2 (verb-second) or dependent-before-head) have a more organising signifié. In other words: it would be strange to have a language that expresses a meaning like 'cat' or 'table' with a bound morpheme, let alone with a non-segmental form, and it would be equally strange to mark illocution with a lexical verb or an auxiliary (see Hengeveld 2004: 1198-1199). See Van de Velde (2009: 144) for the incorporation of this idea in grammaticalisation theory. 
node in this network has its own features that specify the meaning import of that particular construction. The whole network of constructions in a particular language is called the Constructicon (Evans 2007: 42), and is in essence an extended version of what other theories would regard as the Lexicon, enriched with non-lexical constructions. ${ }^{4}$

Along the vertical schematic-specific dimension in the Constructicon the lower concrete constructions "are sanctioned by" and "inherit features from" the higher schematic construction, and features from lower nodes in the network "percolate" upward to the higher nodes. An example of a - partial and simplified - hierarchical network is shown in Figure 1. The top node is the maximally underspecified "transitive" construction. At the next level there are nodes for the ditransitive, the transitive resultative and the reflexive construction. These three constructions are all sanctioned by the transitive construction, but in different ways: the ditransitive is an "extension" of the transitive construction with an extra participant, the transitive resultative is a blend of the transitive and a resultative predicate, and the reflexive is a lexically more specific instantiation of the transitive, in which the direct object Noun Phrase is filled with the reflexive pronoun. Fully instantiated versions of the ditransitive and the transitive resultative constructions are examples like Hij heeft haar een brief gestuurd ('He sent her a letter') and Hij kuste haar bewusteloos ('He kissed her unconscious'), respectively. At the same time, there are other nodes in the hierarchy that represent constructions that draw on different parent constructions. One of these is a construction that may be called "fake object resultative construction", an instantiation of which is Hij loopt zijn schoenen stuk (lit. 'He walks his shoes broken'). In actual fact, it is not really a separate construction next to the transitive resultative construction, but an extension of it by inserting a normally intransitive verb (lopen 'walk') in a resultative construction frame, by a process called "coercion". This process shows the power of Construction Grammar, which has fewer difficulties with such constructions than traditional grammar. The intermarriage between the reflexive and the fake object resultative yields a construction which for convenience sake has been termed "fake reflexive resultative" in the network in Figure 1. Constructs instantiating it are of the type Hij schreeuwt zich schor (lit. 'He shouts himself hoarse'). The offshoot of the ditransitive construction and the reflexive is the ditransitive reflexive (Ronny gunt zich een verzetje, lit. 'Ronny grants himself a distraction'), and the combination of this ditransitive reflexive with the caused motion construction gives us the Dutch weg-construction, which is similar to the English way-construction, but has a somewhat different form (see Verhagen 2002, 2003).

4 The term constructicon is said to be originally coined by Jurafsky (1992). 


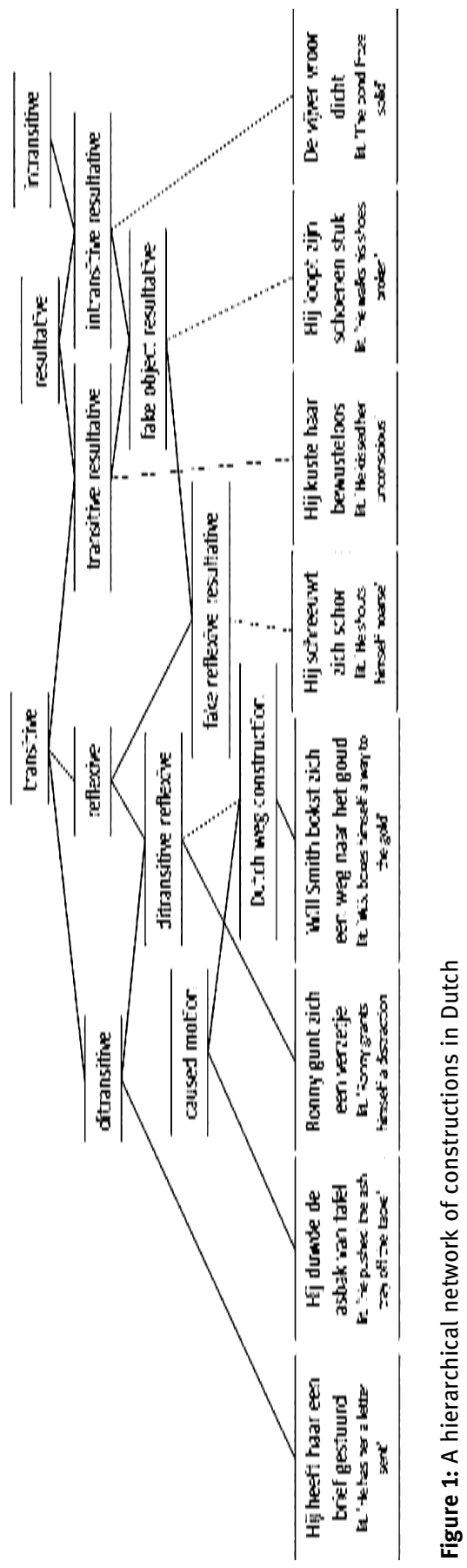


The kind of hierarchical network of constructions with inheritance relations illustrated in Figure 1 is well-known, and features in various scholarly articles on Construction Grammar. There is, however, another respect in which constructions form a network: rather than just forming a hierarchical structure, constructions can also be related to each other on what could be called the horizontal axis. ${ }^{5}$ What I have in mind here is a network where the form-function relation of a particular construction may be partly motivated in relation to its neighbours. This view on networks is familiar from phonology and morphology, but is less often applied to syntax. Before discussing syntactic examples in section 2, I will first elucidate the horizontal relations in a network in phonology and morphology.

In phonology, segmental elements can be related to abstract nodes higher up in the hierarchy thus forming a network not unlike the type illustrated in Figure 1. In Dutch, $/ \varepsilon /$ or $/ \supset /$ are instantiations at the lowest level of the higher abstract node "short front vowel" and "short back vowel", respectively. The latter nodes straightforwardly instantiate nodes of an even higher level. This is all illustrated in Figure 2.

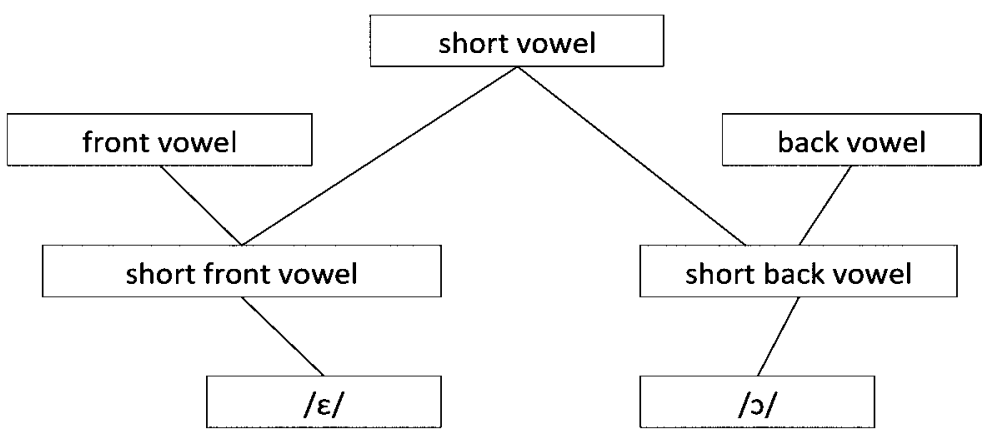

Figure 2: Partial hierarchical network in Dutch phonology

The hierarchical network can be enriched by adding lines for horizontal relations. There is a relationship between the two vowels at the lowest level:

5 Taylor (2004) also embraces the idea of constructions forming networks: “(...) each unit stands at the hub of a network of relations to other units" (2004: 49) and speaks about horizontal relations in constructions, but he refers to something else, viz. the relationship between a structure and a larger structure of which it is a part, e.g. the relation between a Noun Phrase and the clause in which the Noun Phrase functions as, say, a direct object. By contrast, horizontal networks in this paper refer to structures of differential relationships between NPs functioning as subjects, direct objects, indirect objects etc. (see section 2.2). 
they share the features [+ vowel] and [+ short] and are differentiated by the feature [ \pm front] (and also [ \pm rounded], but this is ignored here in order not to complicate the issue unnecessarily). It is not just the vowels themselves that entertain this horizontal relation, but the abstract nodes as well. The boxes for front vowels and back vowels are not just arbitrary notions, but are in a contrastive set ([+ front] and [- front]), and the different values impact on the meaning. By contrast, the nodes [reflexive], [ditransitive] and [resultative] in Figure 1 do not stand in such a contrastive relation: there is no sensible interpretation of [+ reflexive] as [-ditransitive]. In Figure 3, double-headed arrows are added to bring out the horizontal relationships in the phonological network.

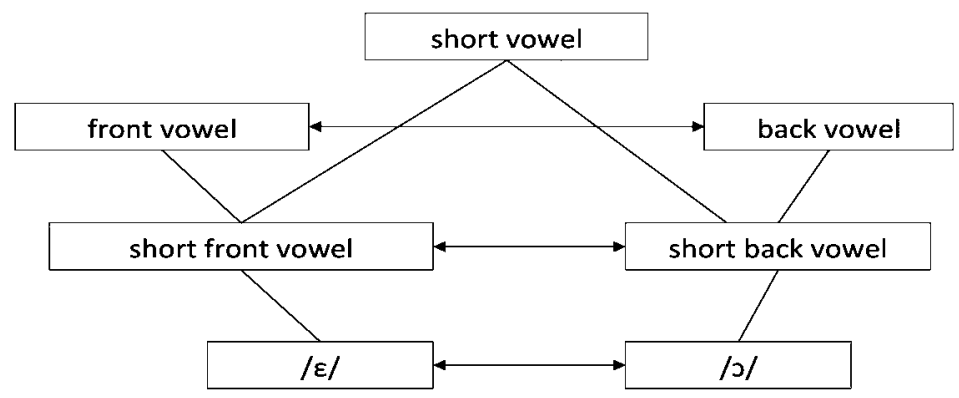

Figure 3: Partial hierarchical network in Dutch phonology with horizontal relations added

In morphology, horizontal relations in networks are well-known, and are mostly referred to as "paradigms". The Dutch verb forms spreek (speak.1sG), spreekt (speak.2/3sG), spreken (speak.PL) are all connected in a large network, but their mutual relation is, again, not one of instantiation. Rather they are at the same hierarchical level and are horizontally differentiated by the inflectional endings. ${ }^{6}$ The horizontal relations in the constructional network in Figure 4 are again visualised by double-headed arrows. The existence of similar "paradigms" outside conjugation or declination has received less attention. Nonetheless, horizontal relations in constructional networks can be discerned at the level of syntax as well, as will be shown in the next section.

6 The situation is complicated by the existence of homonymous forms: spreek is also the imperative form of the verb spreken and spreken can be an infinitive as well as a plural form. Moreover, with post-verbal subjects, the form for 2sG is not spreekt but spreek. These complications will be ignored in the present paper, where the morphological example merely has an expository function. 


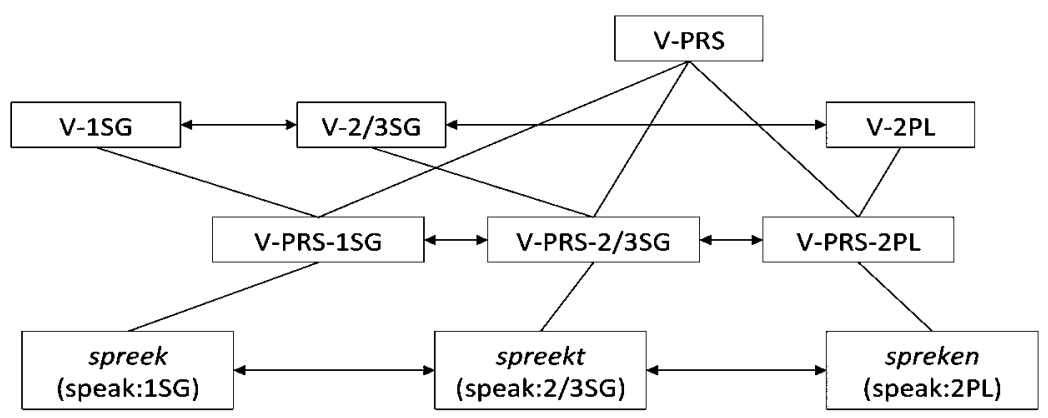

Figure 4: A hierarchical network with horizontal relations added

\section{Horizontal constructional relations in syntax}

In the previous section, we have added horizontal lines to the phonological and morphological networks that take the same form as the typical networks in Construction Grammar of the type illustrated in Figure 1. In itself, adding such horizontal lines does not yield new insights to what we know, of course. Contrastive relations have always been recognised in phonology and morphology, and they feature prominently in all handbooks of classical languages. The question that arises is to what extent such horizontal relationships also play a role in syntax, where the existence of paradigms is less obvious, or at least less often explicitly acknowledged. What would constitute a syntactic paradigm - a set of alternating forms with related meaning differences?

In sections 2.1-2.3, three examples are introduced of horizontally defined syntactic constructions in a network: (i) the position of the finite verb in Dutch clauses, (ii) the case frames of Dutch experience predicates and (iii) the integration of subordinate clauses in Dutch. The latter two examples will be of special interest, as they will be at the focus of the diachronic investigation in section 3.

\subsection{The position of finite verbs in Dutch clauses}

One example of a syntactic paradigm defined by horizontal relations in a network is the position of the finite verb in Dutch clauses (or German clauses, for that matter). In declarative main clauses, the verb is in second position (often abbreviated as "V2" position). The finite verb can occur in other positions as well, however, and these positions have a syntactic meaning: initial verbs (V1) occur in polarity questions, conditionals and imperatives. These contexts can 
be unified under "non-assertive" meaning. ${ }^{7}$ Finite verbs can also occupy the clause-final position $(\mathrm{Vn})^{8}$, typically in subordinate clauses, which can be seen as conveying the meaning of "backgrounding" (see Van der Horst 1984: 172175). The various positions of the finite verb in Dutch clauses form a "paradigm" and are related to each other through horizontal relations of contrast, as visualised in Figure 5.9

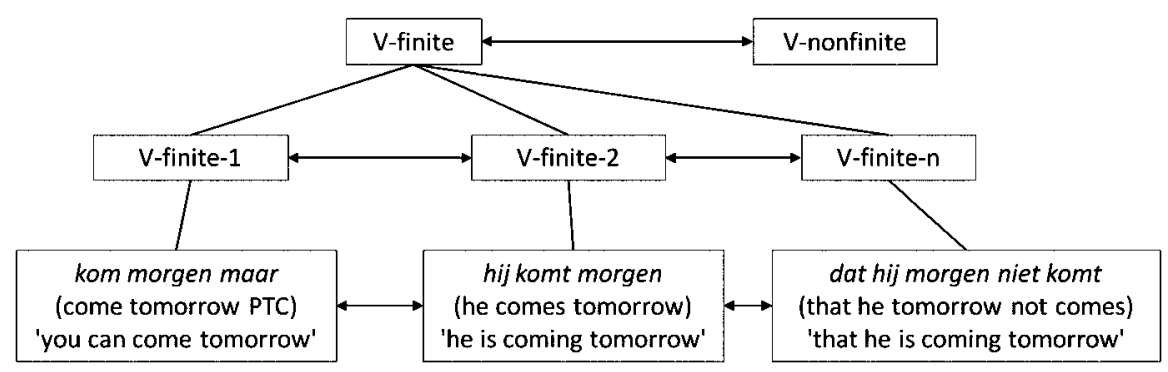

Figure 5: The position of the finite verb in Dutch clauses as a constructional network with horizontal relations

\subsection{Case frames in Dutch experience predicates}

Another example of a set of constructions entertaining horizontal relations of contrast is the argument realisation network in Middle Dutch. Middle Dutch relies on case frames for indicating the agentivity of the participants (Van de Velde 2004). Agentivity can be broken down into features like volition, responsibility, control, animacy, instigation, movement etc. (Lakoff 1977; Dowty 1991; Næss 2007; Grimm 2011, among others). Glossing over the details, which are much discussed but are not our immediate concern here, the whole system is then fairly straightforward, and is well-known from other Indo-European languages: the nominative is used for animate participants, exerting volitional control and instigating the action. Accusatives, on the other hand, are used for non-agentive undergoers, who have no control over the action expressed by the

7 See Goldberg and Del Giudice (2005) for a similar proposal concerning the historically related English subject-auxiliary inversion.

8 Vn does not necessarily mean the very last position in the clause. Hence, it is more accurate to speak about V-late than about V-final.

9 Interestingly, the syntacticisation of V1 and V-late is probably a diachronic corollary of the emergence of V2 (see Hopper 1975; Van der Horst 2008): V1 and V-late only acquired grammatical significance in contrast to V2. This shows that the horizontal lines do capture something substantive in language. 
predicate. The dative case is used for sentient, volitional, but non-instigating participants (see Næss 2007: 198 for a similar proposal), and genitives are used for mainly inanimate patients that are not fully affected by the action expressed by the predicate. This yields a cline of cases, as represented in (1), in which dative and genitive occupy the space in the middle, between the highly agentive nominative and the highly patientive accusative.

(1) Agentive nominative - dative - genitive - accusative NON-AGEnTIVE

(PATIENTIVE)

These are the prototypical functions of the different cases, from which language users can deviate on semantic grounds. ${ }^{10}$ It is, for instance, not uncommon to encounter animate accusatives, and to the extent that animacy is correlated with (or part of) agentivity, this poses a conflict. The accusative then highlights the fact that the undergoer is non-instigating, fully affected etc., glossing over the animacy aspect. In languages where the animacy is given higher priority, this can lead to so-called differential object marking, as in Spanish or Afrikaans, where animate objects can be preceded by a preposition, $a$ and vir, respectively.

An insightful way to account for the assignment of case in Middle Dutch is by taking a constructional approach, in which, unlike in a projectionist approach (see Levin and Rappaport Hovav 2005 for this term), verbs do not assign case automatically according to the valency with which they are registered in the lexicon, but rather select a case frame that contributes its own constructional meaning. The whole system can best be seen at work in verbs that do not straightforwardly map onto the prototypical process in which an actor exerts physical force to affect an undergoer (hit, destroy, break ...). This is, for instance, the case with so-called experience processes, expressing mental and sometimes also physical experiences such as amaze, wonder, annoy, forget etc. It is not clear who is the instigator in the case of annoy, and whether the participants involved - the experiencer or the stimulus - are volitionally implicated. Nor is it clear to what extent the annoyee is really affected. A similar case can be made for amaze and forget, for instance. What we see in Middle Dutch then, is that such verbs occur with a wide range of case frames. For the verb wonderen

10 In fact, the use of case-marking in argument realisation is derivative from their earlier function in spatial marking (see also the localist hypothesis). With the exception of the nominative, which probably is merely the absence of case (Van der Horst 2008: 145, referring to Schuchardt), the cases also have or had a role in the expression of essive relations. Accusative could be used to express adessive (cf. Latin Romam ire) and the genitive, as its name suggests, expresses the abessive, or "source", whether the source of possession, the source of an experience etc. 
('amaze', 'astonish', 'surprise'), the examples in (2) to (5) give an idea of the attested variation. ${ }^{11}$

(2) NOMinative-stimulus, DATIVE-EXPERIENCER

Sere wonderde Pharaone sine vulmaectheit so scone much amazed Pharao:DAT his:NOM perfection:NOM so beautiful 'Pharao was amazed by his very beautiful perfection.' (MNW, s.v. wonderen)

(3) Genitive-STIMUlus, DATIVE-EXPERIENCER

Des wondert mi utermaten

this:GEN amazes me:DAT highly

'I was highly astonished by this.' (MNW s.v. wonderen)

(4) NOMinative-EXPERIENCER, ACCUSATIVE-STIMUlus

Die goede man, die in clenen dingen die

the good man who:NOM in little things the:ACC

grootheit van onsen here plach te wonderne wel zere greatness:ACC of our:DAT lord:DAT used to amaze well very 'The good man, who used to be highly amazed about the greatness of our lord by little things.' (MNW, s.v. wonderen)

(5) NOMINATIVE-EXPERIENCER, GENITIVE-STIMULUS

Si wondrens sere algader

they:NOM wonder=this:GEN much altogether

'They were all highly astonished about this.' (MNW, s.v. wonderen)

The language user can opt for the strategy of pressing the experience verb wonderen in the canonical transitive mould, as for example in (4). But since the experiencer is a non-prototypical agent, it may be encoded as a dative as well, and since the stimulus as well is a non-prototypical agent or patient, it can get genitive encoding. As is shown in (3), there is no need to have a nominativemarked subject. The so-called impersonal construction has a third person singular verb with obliquely marked participants. This shows that the classical two-way typological distinction between experiencer-subject and experiencer-object verbs

11 The examples under (2)-(5) do not exhaust all the possibilities. Apart from case-based argument realisation, there were also voice-based strategies (see Van de Velde 2004 and below). For a resolution of the difficulties posed by case syncretism etc., see Van de Velde (2004: 73-76). 
is a gross oversimplification for Middle Dutch (unless the notion of subject is stretched considerably). ${ }^{12}$

In Van de Velde (2004) it is shown that the distribution of the different constructions over the experiencer verbs is semantically motivated: verbs with an inherently more agentive experiencer (e.g. denken 'think') are statistically more likely to go with case frames that acknowledge the agentivity of the experiencer, whereas verbs with an inherently less agentive experiencer (e.g. ontbreken 'lack') are more likely to encode the experiencer as an undergoer. Verbs like wonderen take a middle position, and excel in the use of the impersonal construction exemplified in (3). Focusing on the cases where the verbs come with two arguments, thus ignoring cases like (6) and (7) without an explicit stimulus and without an experiencer respectively, the different case frames can be ordered on a cline from agentive to non-agentive experiencers, see Table 2. Experiencers are seen as maximally agentive when they are the subject of a regular transitive nominative-accusative construction, as this is the construction that is used for straightforwardly transitive verbs like break, destroy etc. Marking the stimulus with genitive case decreases the agentivity of the experiencer as the stimulus is now represented as not fully affected, and thus somehow escapes the control of the experiencer. The next level is the so-called "impersonal construction" with a dative and a genitive argument, representing a twofold deviance from the transitive frame. The experiencer can be represented as even less agentive, when the stimulus is in the nominative, marking the latter as the starting point of the causal chain.

(6) NOMINATIVE-EXPERIENCER, NO STIMULUS

Alle diet sagen an, wonderden wijf ende man
all who=it saw to amazed woman and man

'All who saw it, both women and men were amazed.' (MNW, s.v. wonderen)

(7) GENITIVE-STIMULUS, NO EXPERIENCER

Waer dat zake dat zijns ontbrake

were it case that he:GEN lack

'If it is the case that he is lacking (= he is dead).' (MNW, s.v. ontbreken)

12 I will not dwell on the applicability of the notion subject in non-canonically case-marked predicates in Middle Dutch. On this topic, see Weerman (1988), Eythórsson and Bardðal (2005) and Bardðal and Eythórsson (2012). 
Table 2: Case frames ordered on a cline of experiencer agentivity

Agentive EXPERIENCER

Experiencer-nominative; Stimulus-accusative Experiencer-nominative; Stimulus-genitive Experiencer-dative; Stimulus-genitive

Experiencer-dative; Stimulus-nominative

Non-Agentive EXPERIENCER

The graph in Figure 6 (based on Van de Velde 2004, with data from the citation corpus of MNW) shows that the case frames are non-randomly distributed over different types of verbs: inherently more "agentive-experiencer" verbs select constructions higher on the cline in Table 2, and vice versa. The correlation is statistically significant. ${ }^{13}$

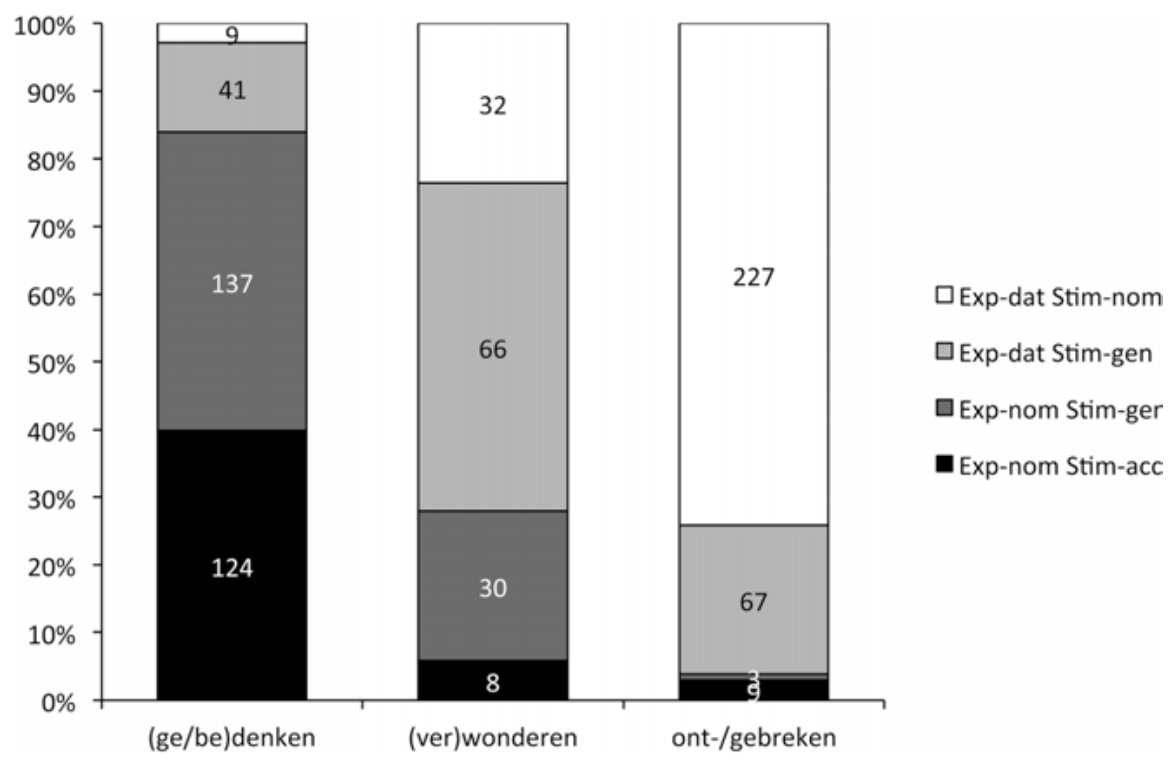

Figure 6: Distribution of constructions over various types of experiencer verbs

The different case frames combining with the experience predicates are horizontally related in the constructional network: differences in meaning are correlated with differences in form, in such a way that we get a cline of closely-

13 Kendall's Tau-b, a test for association, indicates a correlation of 0.69 (Asymptotic Standard Error $=0.02$ ). Chi-Square: $\mathrm{p}<0.0001$. 
related constructions, which are distinguished from one another in the values they have for a set of features. For constructions with experience predicates, the cline goes from "agentive experiencer" to "non-agentive experiencer", and the constructions that form aggregate points on a cline do not entertain a hierarchical relation to each other, but are related in a horizontal way. The case frames can be seen as a cluster of constructions at a certain horizontal level in a constructional network (see also Trousdale 2008: 308, Figure 3 for a visualisation).

\subsection{Subordination}

In the domain of clause combining, the degree of syntactic integration may iconically correspond to the degree of semantic integration (see Cristofaro 2003). Starting from the layered structure of the clause in which arguments and satellites are attached at various levels from the predicate up to the clause (Foley and Van Valin 1984; Hengeveld 1989; Cinque 1999), it can be shown that lower-level satellites such as time adverbial clauses tend to be better integrated than higherlevel relations such as concessives (see Lehmann 1988; Hengeveld 1998; Croft 2001; and, specifically for Dutch, Smessaert et al. 2005). The question is of course how to measure "integration". For Dutch, we are in the fortunate position that its verb-second main clauses offer a clue to integration: if the subordinate clause triggers inversion in the main clause, it is integrated, as it occupies the first position, "pushing" the subject to post-verbal position. If, on the other hand, the subordinate clause is followed by subject-verb word order (no inversion), then it is in left-detached position. ${ }^{14}$ By way of illustration, let us take a look at two different types of syntactic constructions:

(8) Toen hij thuis kwam, begon het te regenen. when he home came began it to rain

'When he arrived home, it started to rain.'

(9) ${ }^{\star}$ Toen hij thuis kwam, het begon te regenen. when he home came it began to rain

(10) Al is hij ziek, hij komt toch. even_if is he ill he comes anyway

'Even if he is ill, he is still coming.'

14 I assume the reader has a basic idea of the word order principles in Dutch clauses. If not, the reader can be referred to Haeseryn et al. (1997: 1221-1400), Verstraete (2003) or Zwart (2011). 
$\begin{array}{llllll}{ }^{*} A l & \text { is hij ziek, } & \text { komt hij toch. } \\ \text { even_if is he ill comes he anyway }\end{array}$

The temporal subordinate clause in (8) obligatorily triggers inversion in the main clause, whereas the concessive clause in (10) is obligatorily followed by subject-verb word order. ${ }^{15}$ This is not a coincidence, but iconically reflects the higher level of attachment of concessive clauses. If the only indication of the level of attachment would be the presence or absence of inversion in the main clause, this would of course be a circular argument, but fortunately, there are other semantic and formal considerations: temporal adverbial clauses trigger tense agreement ("consecutio temporum"), but concessive clauses can under certain circumstances bail out, see (12) vs. (13).

(12) Toen hij thuis kwam/*komt, begon het te regenen. when he home came/comes began it to rain 'When he arrived/*arrives home, it started to rain.'

(13) $\mathrm{Al}$

Al staat/stond hij niet als erg betrouwbaar bekend, even_if stands/stood he not as very reliable known

hij sprak toen de waarheid.

he spoke then the truth

'Even if he is/was not known to be very reliable, he nevertheless spoke the truth back then.'

This can be seen as an indication that the (ook) al-concessive clauses are less integrated in the main clause, the reason being that they are separately asserted. This also explains why they behave differently with regard to clefting: concessives cannot (easily) be clefted (see Smessaert et al. 2005), and why concessives more easily allow speech act adverbs, such as eerlijk gezegd ('honestly said'). ${ }^{16}$

What examples (8)-(11) show is that integration vs. non-integration as signaled by the presence or absence of inversion of the main clause verb is a

15 Note that (ook) al concessives are different in another respect as well: they do not feature verb-final syntax of typical subordinate clauses, but rather have verb-initial (in fact V2) syntax in the subordinate clause. I will come back to this issue below.

16 Space limitations prevent an in-depth illustration of all possible types of subordinate adverbial clauses in Dutch. I will ignore the fact that there is a third pattern: semi-integration, in which the subordinate clause is in left-detached position, but is resumed by a correlative element in sentence-initial position in the main clause, so that the subordinate clause is at the 
cue for the language user to partly assess the semantics of the subordinate clause. In principle, one could argue that the integration of the subordinate clause is lexically projected from the conjunction, but this is not the case. Just as with argument realisation, a constructional approach is superior over a projectionist approach, as the template (integration/non-integration) carries meaning of its own, although some degree of convention always limits the possible variation. In the case of integration/non-integration, the semantic contribution of the constructional template can be seen at work in the use of several conjunctions which allow both construals. As shown by Smessaert et al. (2005), many a Dutch conjunction occurs both in integrated and non-integrated patterns (e.g. aangezien 'since', vooraleer 'before', als 'if', terwijl 'while', tenzij 'unless'), but the two construals yield different readings. Take for instance the conditional conjunction als. If the conditional clause modifies the state-of-affairs, the conditional is integrated and triggers inversion in the main clause. If the conditional clause modifies the speech act, it is attached at a higher level. There is a vast literature on the topic (Davison 1981; van der Auwera 1986; Sweetser 1990, among others), but the difference can easily be illustrated with the set of examples under (14)-(15).

(14) Als het regent, word je nat. if it rains get you wet 'If it rains, you'll get wet.'

(15) Als je het nog niet gezien hebt, het regent buiten. if you it yet not seen have it rains outside 'In case you haven't noticed, it’s raining outside.'

There are other conditionals introduced by als that fail to trigger inversion in the main clause, but the non-integrated nature is motivated here as well: either they border on concessive meaning, as in (16) (from König and van der Auwera 1988: 112), or they are subjunctive (or counterfactual), as in (17) (from

same time integrated and non-integrated. The picture is rather complicated for Dutch (see König and Van der Auwera 1988 and Van der Horst 2008 for details). The reason this pattern is ignored is that it only rarely occurs as the only possible pattern in Present-day Dutch (see Smessaert et al. 2005, appendix A). Furthermore, I will concentrate on sentence-initial subordinate clauses only here. Also, the presence of the subordinator dat is not taken into consideration here. In some subordinate adverbial clauses, it is obligatory (e.g. omdat), in other subordinate adverbial clauses, it is optional (be it substandard) (e.g. toen dat, hoewel dat) and in still other contexts it is excluded (e.g. als ${ }^{*}$ dat). 
König and van der Auwera 1988: 114). Note that in the latter case, integrative construal with inversion is also possible, unlike conditionals like (16).

(16) Als ik als schilder slecht was, als metselaar was if I as painter bad was as mason was

$i k$ echter een katastrofe/succes.

I however a catastrophe success

'If I was bad as a painter, as a mason however I was a catastrophe/success.'

(17) Als ik in jouw plaats was, ik zou hem aanklagen.

if I in your place was I would him sue

'If I were in your position, I would sue him.'

To summarise, integrated vs. non-integrated patterns of subordinate clauses are horizontally related in their constructional network. It is only in contrast to integration that non-integration is semiotically meaningful. There is crosslinguistic variation in the absolute degree of syntactic integration of time adverbial clauses, and it is only by comparing the different subordinate constructions that the motivation becomes clear, so that whatever degree of integration a temporal subordinate clause has in a language, it will not be less integrated than a concessive clause. The precise formal features that define the network are language-specific: obviously, the criterion of inversion only works in a V2 language (see also Verstraete 2003).

\section{The diachrony of horizontal constructional relations}

\subsection{Language change as a "threat" to horizontal constructional relations}

In the previous sections, a number of horizontally organised constructional networks have been discussed, to wit, vowel features, verbal inflection, position of the finite verb, case frames in experience predicates, and integration of subordinate clauses. Evidently, each of these networks can get tousled when one of the differential values increases its scope. Suppose all vowels become [+ front], then the difference between [+ front] and [- front] is no longer able to discriminate words. Or suppose that analogical leveling in verbal inflection paradigms blots out the person desinences. In that case, the inflectional paradigm ceases to exist. 
This is not so far-fetched: the history of the verbal inflection in Proto-Germanic, Dutch, English and Afrikaans is largely one of far-reaching analogical leveling.

In the syntactic case studies, introduced in section 2, language change similarly can bring down the network of horizontal relations. In principle, Dutch could extend its V2 to subordinate clauses, thereby obliterating the semiotically relevant distinction between V2 and Vn. Again, this is not far-fetched, as such a change occurred in English. In the following sections 3.1 and 3.2, a closer look is taken at the history of the other two syntactic examples, as these have in fact come under pressure by diachronic drifts elsewhere in the language system. The case frames in Dutch experience predicates came under pressure in Middle Dutch, and the integration level of subordinate clauses has recently come under pressure.

In both cases, however, it can be shown that the semantic differences that are formally expressed by the horizontally related nodes, survive. The reason is that these semantic differences are degenerately expressed. Crucially, the degenerate strategies are not instances of what is traditionally called "renewal" (Hopper and Traugott 2003: 122-124): it is not the case that language users come up with new ways to express semantic distinctions which they used to express differently. Rather, grammatical strategies that already existed in the language and already played a role in the functional domain at issue are seized upon to "rescue" the system.

\subsection{Case study 1: Case frames in Dutch experience predicates}

The delicate case-frame network laid out in Table 2 came under pressure when the case system of Middle Dutch broke down in a process that is commonly called "deflection". When dative- and genitive-marked objects die out, the constructions that deviate from the canonical transitive construction become indistinguishable.

As is well-known, the loss of case in Dutch was compensated for by the increased use of prepositions. It is easy, however, to be misled by this metaphor of "compensation". In its naive form, it could be taken to suggest that prepositions arose when the case system broke down. This does not conform to the actual facts, however. Prepositions already existed in Middle Dutch, and were used in combination with case. A more accurate way of describing the actual development is that an already existing strategy was exploited by language users. This is a clear case of degeneracy: prepositions were not specifically designed as a trade-off means of expressing case in argument realisation, and the two strategies are not always completely interchangeable, but there is a 
certain amount of functional overlap so that the language system can sustain loss of one of the strategies. By way of illustration, take example (18), where the impersonal construction is realised by encoding the stimulus as a prepositional object introduced by van which is equivalent to the genitive in other contexts, such as possession, as well.

\section{(18) Hen allen wonderde van dien they:DAT all:DAT amazed of this:DAT 'They were all amazed by this.' (MNW s.v. wonderen)}

Still, this strategy was not exploited in full, as the substitution of a dative by a prepositional object introduced by aan or voor does not appear to occur. (If the preposition aan occurs, it is one of the alternatives to the van preposition for encoding the stimulus, see 19 and below). ${ }^{17,18}$

\section{(19) Alle konsten daer men sich aen verwondert all arts where one himself to amazes 'All arts by which one is amazed.' (WNT s.v. verwonderen (I))}

There is one construction in present-day Dutch that closely resembles the Middle Dutch impersonal construction, as neither of its arguments is encoded as subject, see (20) and (21). The subject role is taken by a dummy het ('it'), the stimulus argument is marked by the preposition aan ('to') and the experiencer is encoded as an object, with oblique forms in case of pronominal realisation, as in (20). The construction is odd as it does not occur with those verbs that were most strongly associated with the impersonal construction in Middle Dutch, such as (be/ver)wonderen, but rather with a few verbs that belong to the stimulussubject category: ontbreken, mangelen, schorten, all of which can be glossed 'lack'.

(20) Het ontbreekt hem aan geld.
it lacks him to money
'He lacks money.'

(21) Het ontbreekt die mensen aan geld.
it lacks those people to money
'Those people lack money.'

17 The analysis of (19) is complicated because the complement of the preposition is daer, constituting what is called in Dutch grammar a (separable) pronominal adverb.

18 Other prepositions occur as well: $a f$, in, om, in, over (see WNT s.v. verwonderen I). 
To summarise, while degenerate marking by preposition existed and was exploited to partially make up for the gradual loss of case inflection, there was no full hand-off between both strategies: prepositional marking did not reach its full potential. Instead, language users relied on other degenerate strategies.

One of these degenerate strategies was the increased use of the plain transitive construction with experiencer subjects: over the centuries, Dutch experiencer predicates undergo a drift towards more experiencer-subjects. The drift from dative-experiencers to nominative-experiencers is by no means restricted to Dutch. It is a cross-linguistically rather common tendency and has been analysed from the perspective of grammaticalisation (see Haspelmath 1998: 338-340). From the perspective of Construction Grammar, the process has been ascribed to the extension/schematisation of the transitive construction (Trousdale 2008). For Dutch, this extension of the transitive construction is corroborated by a corpus study on (be/ver)wonderen 'amaze', the prime example of an experience verb that tended to occur in the impersonal construction in Middle Dutch (see Figure 6). ${ }^{19}$ Using data from two corpora, KLASLIT and LITEROM, the bar chart in Figure 7 shows a diachronic increase in the use of the transitive construction after Middle Dutch. ${ }^{20}$ Transitive constructions are those with a subject

19 The prefixes be- and ver- have an impact on the meaning of the verb, of course. Bewonderen, with the applicative be-prefix involves higher agentivity on the part of the experiencer. The question is whether to include bewonderen in the corpus study. Its applicative nature implies a strong tendency to occur in the transitive construction, and it could be argued that it would be better to leave the instances of bewonderen out of the corpus study, as it risks to overestimate the transitivity drift. Still, there are good reasons to retain bewonderen in the counts. First, it semantically overlaps with (ver)wonderen: on the one hand Middle Dutch (ver)wonderen could carry the meaning of present-day Dutch bewonderen ('admire'), as in the following example: Nochtan so verwondert die natuer die suverlijcheit ('Still, nature admires pureness') (MNW s.v. suverlijcheit). On the other hand, Early Modern Dutch bewonderen does not consistently mean 'admire', but can be used in the sense of 'amaze' as well (see WNT s.v. bewonderen). Moreover, it does not consistently occur in the plain transitive experiencer-subject construction, but occurs in the inverted source-subject construction (Het bewonderde mij 'it APPL=amazed me' (WNT s.v. bewonderen)) and in the reflexive as well, as in: Zoo men (...) binnens-Lands nog sommige Kaakenbeenderen van Walvisschen, 't zy in Klai, Veen of Zand, verkalkt of versteend mogte ontdekken, behoeft men zig ... deswegens niet te bewonderen ('If one would discover some calcified or petrified whale cheek bones inland, be it in clay, peat or sand, one should not be amazed by it') (WNT s.v. bewonderen). In short, there is no hard and fast distinction, neither in meaning nor in argument realisation, between bewonderen on the one hand and (ver)wonderen on the other hand. This is the reason why we treat bewonderen and verwonderen together in the corpus study. I will return to the role of the prefixes below.

20 The correlation is statistically significant: Kendall's Tau-b 0.28, ASE 0.07. Chi-Square: $\mathrm{p}<0.0001$. 
and a non-prepositional object. Examples are given in (22)-(23). Dutch has not decidedly converged on experiencer-subjects for its transitive construal, but allows stimulus-subjects as well, but Figure 8 shows that within the group of transitive constructions, the experiencer is nevertheless increasingly likely to be encoded as subject - a process which has been observed in English too (see Allen 1995). ${ }^{21}$

(22) Ik bewonder hun schaamteloosheid.

I admire their shamelessness

'I admire their shamelessness.' (21st century, LITEROM)

(23) Neen, maar het verwondert me niet.

no but it astonishes me not

'No, but it does not surprise me.' (21st century, LITEROM)

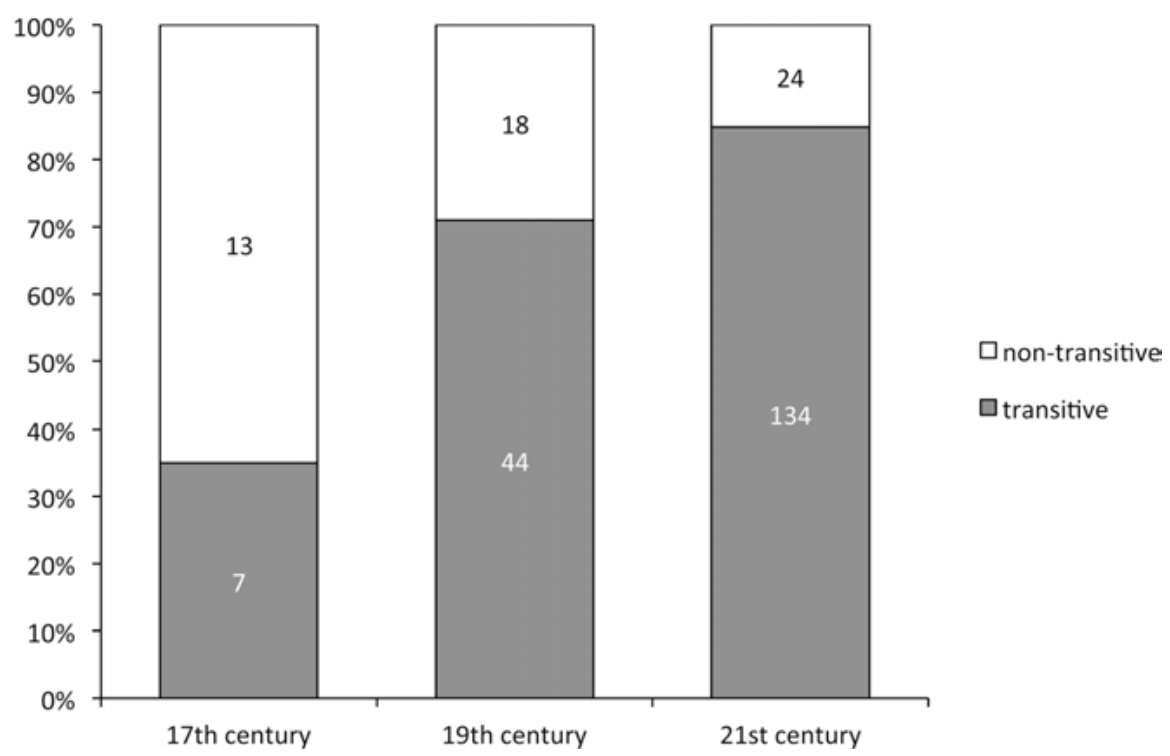

Figure 7: The diachrony of the transitive construction with (be/ver)wonderen in Modern Dutch

21 The correlation is statistically significant: Kendall's Tau-b 0.56, ASE 0.04. Chi-Square: $\mathrm{p}<0.0001$. 


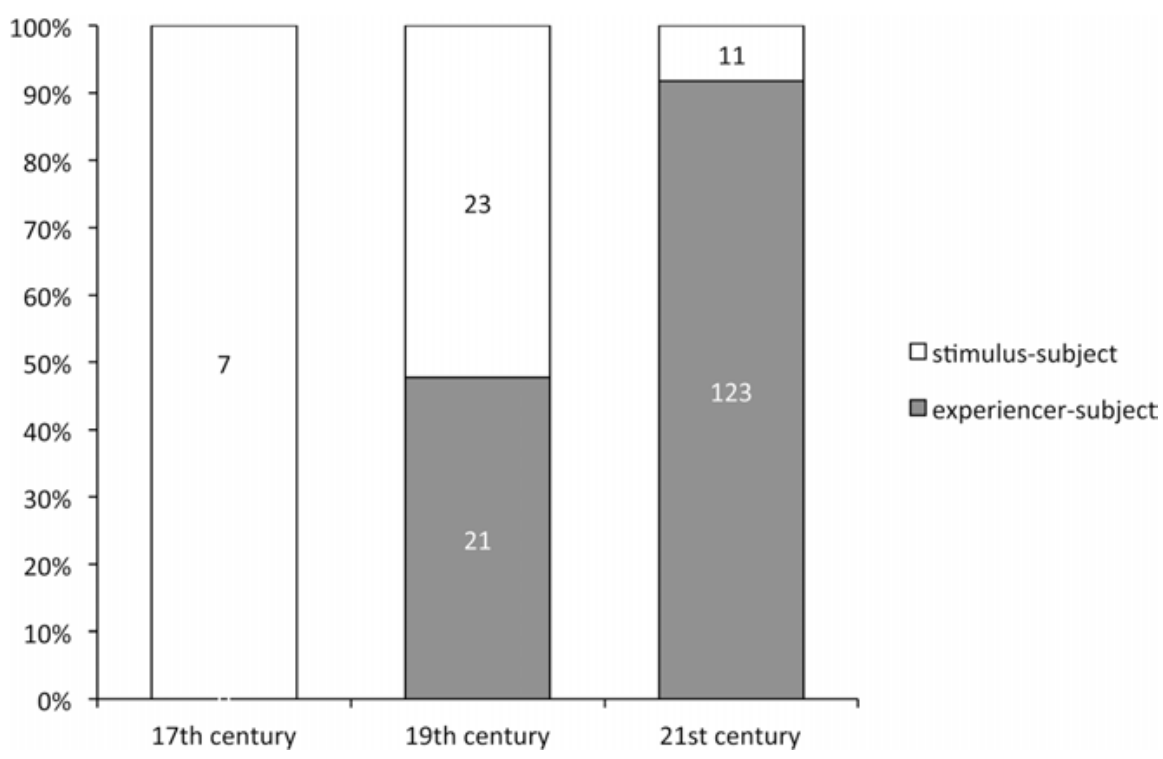

Figure 8: Experiencer-subject vs. stimulus-subject in (be/ver)wonderen

A closer look at the diachrony of the argument realisation of (be/ver)wonderen shows, however, that the transitivity drift is not the only thing that is going on. Dutch turns out to deploy other degenerate ways to maintain the meaning differences primarily carried by case frames in Middle Dutch. Rather than yielding completely to an undifferentiated transitive construction, Dutch exploited existing voice distinctions to re-establish the middle ground that was formerly covered by (double-)oblique case frames. More specifically, there are two constructions that take over this function, namely the reflexive, exemplified in (24), and the static passive, exemplified in (25). Again, we are dealing with degeneracy here, rather than pure renewal, as the reflexive and the (static) passive already existed in Middle Dutch, and just extended their use (frequency and context) in Dutch.

(24) Ik verwonder mij daarover.

I amaze myself there_about

'That amazes me.' (21st century, LITEROM) (25) ... dat je over alles even verwonderd was.
that you about everything equally amazed '... that you were equally amazed by everything.' (21st century, LITEROM) 
If we plot the distribution of all these constructions through time (see Figure 9), they appear to become less popular, but our view is clouded by the fact that morphology plays an important role here. ${ }^{22}$ The apparent decrease in the use of the reflexive and static passive is due to the rise in the transitive construction. The latter construction, however, cannot be used without altering the morphology of the verb wonderen. In order to use it transitively, it has to be preceded by a prefix ver- or be-. The prefix be- has an applicative function, turning a predicate from intransitive to transitive (e.g. be-zingen 'sing about'). In this sense, it has, to a certain extent, the same value as the nominative-accusative case frame in Middle Dutch. As becomes clear in Figure 10, the use of this applicative prefix rises precipitously over the centuries - indeed, plain wonderen is not attested anymore in present-day Dutch. ${ }^{23}$ The rise of the applicative shows that language users increasingly encode the process of amazement as transitive. Still, in those cases where they do not use the be- prefix, there does seem to be a rise in the use of the other voices (reflexive + static passive voice combined), at the expense of the plain active-transitive, which is also an option here, as illustrated in (23). This is shown in Figure 11, which gives the diachronic distribution of the constructions ignoring the observations with a be- prefix. ${ }^{24}$ This shows that although language users increasingly rely on the transitive construction, and on the experiencer-subject version of it, they also increasingly use voicebased constructions when they want to deviate from the plain transitive construction.

22 Making the "construction" variable binary by amalgamating the reflexive and the static passive in one category, as opposed to the active transitive, yields the following results: Kendall Tau-b: 0.56, ASE 0.10. Chi-Square: $\mathrm{p}<0.0001$.

23 The reason why Figure 10 plots more observations is that the non-finite contexts (and imperatives) could be included as well, which were obviously ignored in the figures on argument realisation above. The figures have been analysed with a Cochran-Mantel-Haenszel statistic, which tests a matrix with an ordinal variable in the columns and a nominal variable in the rows for the alternative hypothesis that the row mean scores differ. In the case at hand, it tests whether the use for either of the three forms ( $\varnothing$-wonderen, ver-wonderen, be-wonderen) shifts through time. The test value corresponds to a p-value $<0.0001$.

24 The results show that the correlation observed in Figure 9 disappears: Kendall's Tau-b 0.06 (ASE 0.10). Chi-Square $\mathrm{p}=0.12$. (But note that absence of evidence of an association is not the same as evidence of absence of an association.) 


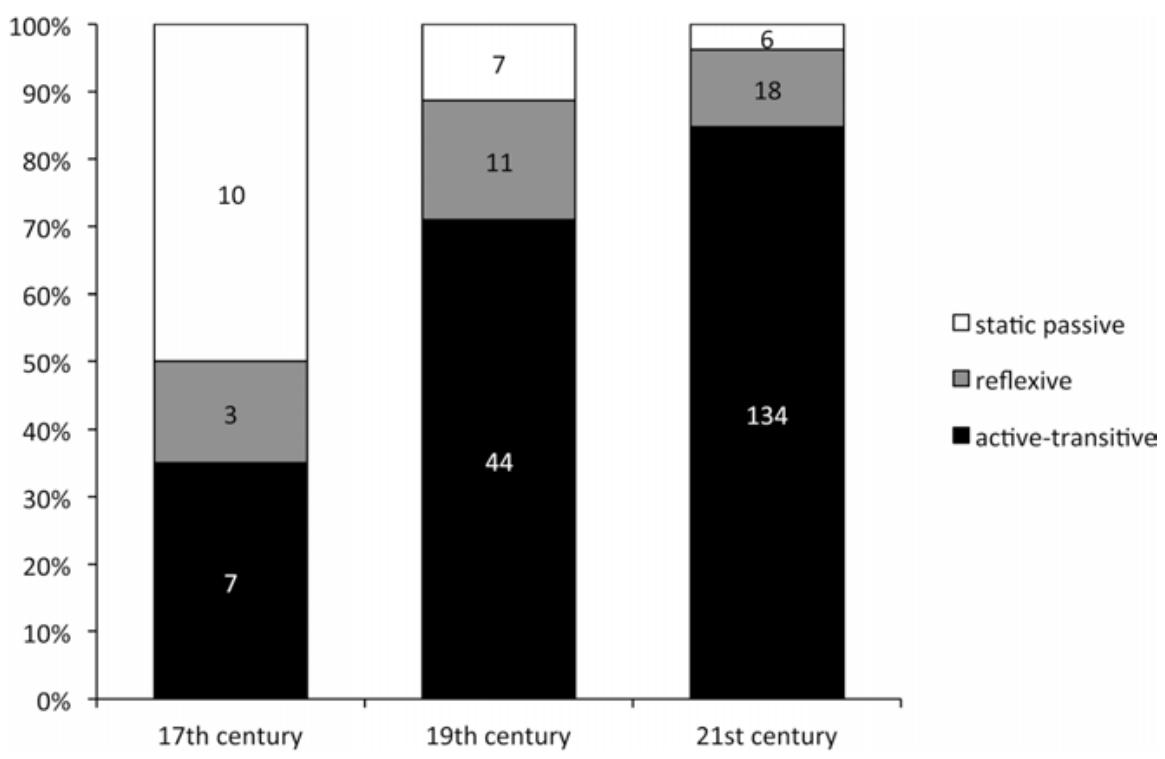

Figure 9: Voice-based constructions with (be/ver)wonderen in Modern Dutch

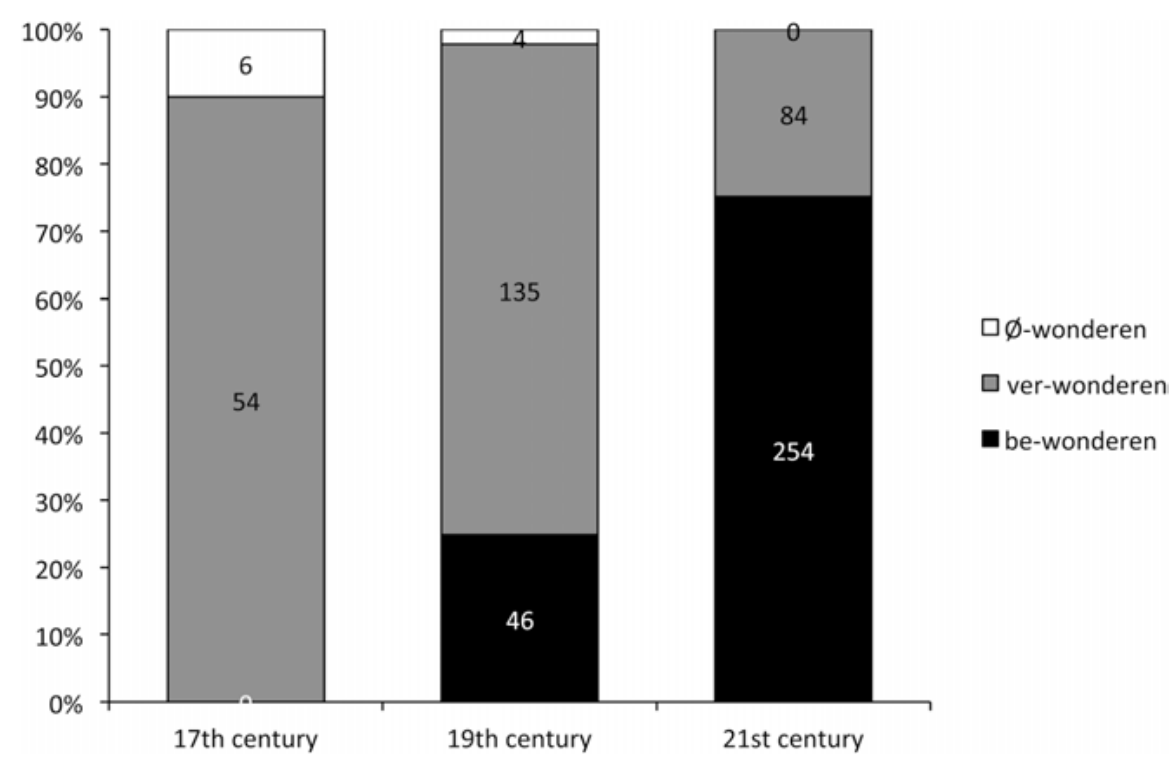

Figure 10: Prefixes in Modern Dutch 


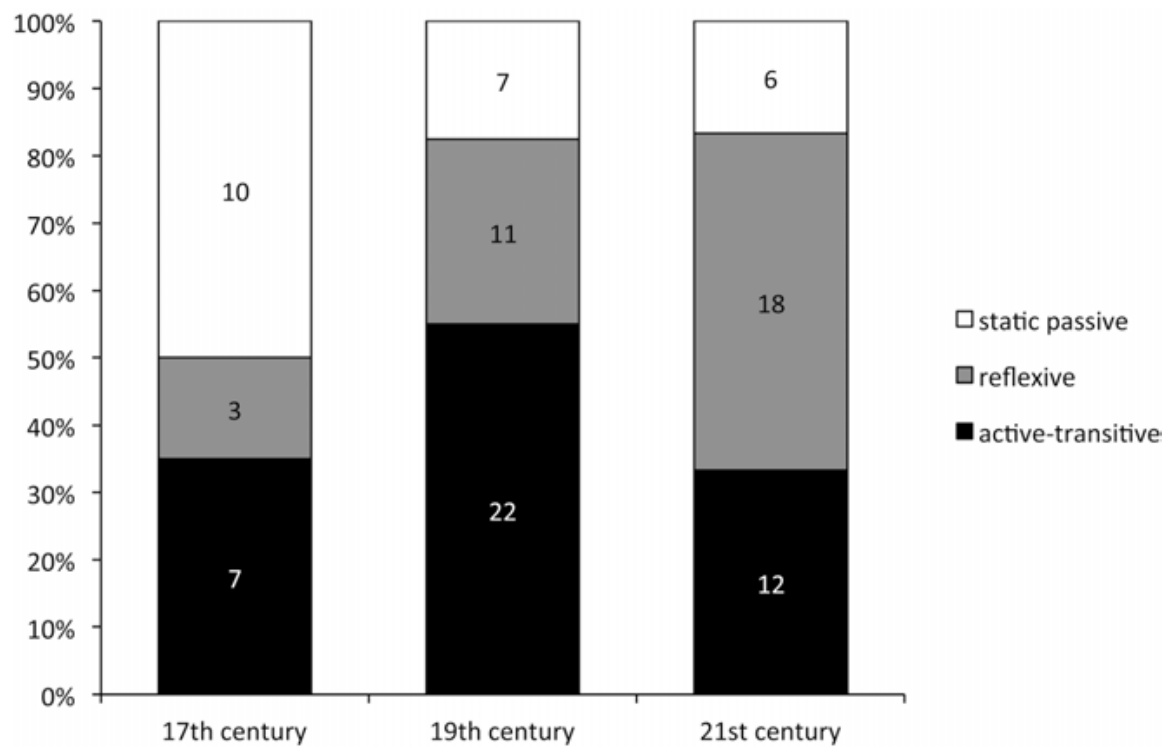

Figure 11: Voice-based constructions with (ver)wonderen in Modern Dutch

Another degenerate strategy compensating for the loss of the fine-grained case-based argument realisation for experience processes in Middle Dutch seems to be an increase in the lexical expressions. Next to (be/ver)wonderen, presentday Dutch has verbs like verbazen 'amaze', versteld zijn 'be amazed', verrassen 'surprise', which did not occur yet in Middle Dutch. This lexical proliferation can be used to express different meanings. It remains to be seen whether this tendency holds up under a more systematic study, but a similar lexical increase has been observed for Middle Dutch vergeten 'forget' (see Van de Velde 2004: 70).

In sum, deflection in Dutch was not as detrimental to the case-based argument realisation of Dutch experience predicates as one might think. Thanks to existing degenerate strategies, the loss of the case system could be sustained without losing the capability of expressing semantic nuances in experience processes. Several alternative strategies were exploited, such as (i) prepositions, (ii) generalisation of the transitive construction, (iii) voice-based distinctions, (iv) applicative prefixes, and (v) lexical differentiation - all of which serve functions outside the argument realisation of experience processes. The actual facts are thus vastly more complex than a simple "transition from cases to prepositions" or a simple "extension of the transitive construction". The multifaceted nature of the diachrony of argument realisation in experience predicates shows how 
Dutch, as a complex adaptive system, benefits from degeneracy both in terms of robustness and evolvability: language users can do away with something as central to grammar as case without running into problems.

\subsection{Case study 2: Subordination}

In the case of subordination, it has been observed that different types of subordinate clauses tend to become more integrated over time (see e.g. Hopper and Traugott 2003: 175-211). Obviously, this undermines one vital part of the system laid out in section 2.3: if concessives have the tendency to become integrated, the criterion of inversion can no longer reliably function as a semantic signal of the degree of integration, and the whole network gets disturbed. ${ }^{25}$ Yet this is precisely what has happened and still is happening in Dutch. Example (26) shows that the concessive conjunction hoewel did not yet trigger inversion in the 18th century, contrary to what is the case in late 20th century Dutch, see (27). Moreover, the concessive conjunction (ook) al, which normally does not trigger inversion, see (10), can occasionally be seen to be used in an integrated construction, triggering inversion in present-day Dutch, see (28). This is still frowned upon in (prescriptive) grammars, but examples can be found even in edited texts.

(26) Hoewel ik haestig ben, het is aenstonds gedaen although I irascible am it is immediately done 'Although I am irascible, it is immediately over.' (18th century, WNT)

(27) Hoewel ik je invitatie heel lief vind, $z a l$ ik niet although I your invitation very sweet find shall I not kunnen komen. can come

'Although I find your invitation very sweet, I shall not be able to attend.' (20th century, WNT)

$\begin{aligned} & \text { Ook al waren zij duur geworden, had zij } \\ & \text { even though were they expensive become had she }\end{aligned}$
altijd veel bloemen om zich.
always many flowers around herself

'Even though they had become expensive, she was always surrounded by a lot of flowers.' (20th century, WNT)

25 I want to thank William Van Belle for pointing this out to me in a discussion of Croft (2001). 
How does the system of Dutch grammar react to the drift of subordinate clauses towards tighter integration? One strategy that is followed is to make the relations lexically explicit. Indeed, the Dutch language witnesses a considerable increase in the fund of conjunctions. Van der Horst (2008: 984) speaks of a proliferation ("woekering") of subordinating conjunctions in Late Middle Dutch and Early Modern Dutch. ${ }^{26}$

In Middle Dutch, the precise semantic import of a subordinate clause was often left implicit, as can be appreciated from the bewildering set of meanings that the simple subordinator dat can convey:

(29) Want dat hi enich erchs verdiende, nemmermeer en for if he any bad-GEN achieved nevermore NEG haddi ons te vriende had=hi us to friend:DAT

'For if he achieved anything bad, he would not have us as a friend anymore.' (MNW, s.v. dat)

(30) Hi hadde (...) hem selven soe siec ghemaect, dat hi he had him self so sick made because he soe vele hadde ghewaect so much had stayed_awake 'He had made himself so sick because he had stayed awake so long.' (MNW, s.v. dat)

(31) Ic hebbe in minen droom van hem ghedoghet

I have in my dream of him thought

dat ics vermoeyt bem

so_that (consequence) I=this:GeN tired am

'I thought about him in my dream, so that I am tired because of it.' (MNW, s.v. dat)

(32) Maria brachte haren sone, dat menne Maria brought her son so_that (goal) one=him:ACC besniden soude circumcise would 'Maria brought her son, so that he could be circumcised.' (MNW, s.v. dat)

26 Leuschner and Van den Nest (p.c.) speak about "conjunctional drift”. 
(33) Si dwoughen sine voete met warmen borne, They washed his feet with warm source_water dat ic wane as_far_as I believe

'They washed his feet with warm water, as far as I know.' (MNW, s.v. dat)

(34) $\mathrm{Nu}$ es Brune die bere ghegaen, dat hi te Maupertuus Now is $B$. the bear gone until he to $M$.

es comen

is come

'Now Bruin the bear set off, until he reached Maupertuis.' (MNW, s.v. dat)

A more specific subordinating conjunction like opdat used to be ambiguous between expressing condition and goal, see (35) and (36), respectively. In present-day standard Dutch, opdat unequivocally introduces subordinating clauses of goal.

(35) Opdat ik maar eenigszins tijd heb, zal ik het doen if I but somewhat time have, shall I it do 'If I have only the slightest amount of time, I will do it.' (18th/19th century, WNT, s.v. opdat)

(36) Hij... hield de lamp omhoog, opdat zij des te beter he held the lamp up so_that they all the better mochten zien. might see 'He held the lamp up, so that they could see (even) better.' (19th century, WNT s.v. opdat)

Still, the view that the grammaticalisation of new conjunctions to make the precise type of subordinate clause more explicit is a "compensatory" strategy for the unstoppable integration of subordinate clauses messing up the iconic system introduced in section 2.3, is incorrect. The reason is that the iconic horizontal network of subordinate clauses developed in sync with the massive grammaticalisation of conjunctions. As shown in Van der Horst (1981, 2008: 538-540, 769-771, 1040-1042), adverbial subordinate clauses of various types, including deeply attached ones, did not yet systematically trigger inversion in the main clause in Middle Dutch, and even later. Weijnen (1971: 13) gives the following example of a non-integrated temporal subordinate clause in Middle Dutch: 


Alsic dit horde ic was in vare
when=I this heard I was in fear
'When I heard about this, I was frightened.'

Burridge (1993: 41) says that the systematic use of inversion in the main clause after a sentence-initial subordinate clause only gains momentum after 1650. It is hence more accurate to say that the use of the main verb position and the lexically specific conjunctions are degenerate strategies to express semantic layering. Just as in the case of experience processes, such a situation of degeneracy prevents the system from collapse when one of the degenerate strategies comes under pressure. The other available strategy does not come out of the blue, but its weight is increased. In other words: the grammaticalisation of new, specialised conjunctions was not really a remedy for the integration of higher-order adverbial subordinate clauses, but maybe it has been sped up by the drift towards integration. ${ }^{27}$

An indication that the two processes are still causally related is the observation that adverbial clauses without a specialised conjunction are more likely to resist integration in the main clause: the unambiguous concessive conjunctions hoewel, ofschoon and ondanks (het feit) dat trigger inversion in the main clause in present-day standard Dutch, ${ }^{28}$ but concessive clauses without a conjunction like (38) do not, suggesting that they need the syntactic clue of (lack of) inversion in the main clause to indicate their adverbial type. The same argumentation applies to concessive (ook) al. This conjunction is not as grammaticalised as hoewel and ofschoon: al retains characteristics associated with its adverbial origin. As shown in (10), al clauses do not sport the characteristic verb-final syntax of Dutch subordinate clauses and as shown in (39), al does not have to be used subclause-initially. ${ }^{29}$ In the latter case, inversion is not possible.

27 This is by no means the only case of degeneracy in Dutch subordination. According to Van der Horst (1981: 182) there is an inverse diachronic correlation between the presence of the expletive default subordinating conjunction dat (as in Middle Dutch hoe dat 'how (that)' and soe dat 'if (that)') and the V-late position of the verb in subordinate clauses.

28 See example (41) for an exception motivated on semantic grounds.

29 Admittedly, non-initial al features in a restricted constructional context. The exact contours of the licensing construction are not clear, but co-occurrence of dan preceding al and the presence of the modal auxiliary mogen seem to be fairly strong restrictions. Still, mogen is not strictly obligatory, as is clear from examples like Ze was dan al wel 18 jaren oud, maar het bleef toch familie he 'Even though she was 18 years old already, she was still family' (Internet example, found by Google search). 
Concessive meaning can also be expressed by the semi-conjunction 'WH-WORD ... ook', as in (40), again without triggering inversion in the main clause. ${ }^{30}$

(38) Had ik gisteren nog hele doemscenario's in mijn hoofd, had I yesterday still whole doom_scenarios in my head vandaag blijkt maar weer dat mijn brein dus ikzelf today appears once again that my brain so myself mijn ergste vijand op dat gebied ben. my worst enemy on that terrain am 'Yesterday I still had full doomsday scenarios in my head, but today my brain - so myself - appears once more to be my own worst enemy.' (Google example)

(39) Want hij mag dan al jong multimiljonair zijn, en for he may then PTC young multimillionaire be and ambassadeur van Mandela, en de nieuwe God van golf, Ernie ambassador of $\mathrm{M}$. and the new god of golf $E$. Els is ook nog steeds een gezonde Hollandse jongen (...). E. is also still a healthy Hollandish boy 'For he may be a multimillionaire at a young age, and the ambassador of Mandela, and the new god of golf, Ernie Els is still a healthy boy from Holland.' (20th century, INL38)

(40) Hoe goed ik ook kijk, ik zal nooit de bron van het how well I also look I shall never the source of the licht kunnen localiseren. light can localise 'No matter how well I look, I will never be able to localise the source of the light.' (20th century, INL38)

So although the criterion of inversion in the main clause emerged relatively late, the horizontal network of Dutch subordination patterns is in competition with the tendency of increasing integration of adverbial clauses. It seems that Dutch currently uses the syntactic clue of inversion for the distinction between integration and non-integration in those cases where the conjunction allows for different types of subordinate clauses, like als, see (14) vs. (15) and hoewel,

30 Van der Horst (2008: 1970) has several 19th century examples of WH-WORD ... ook and al concessive triggering inversion in the main clause, which seem to go against the grain of the integration drift (as Van der Horst points out himself). It is not clear why these concessives enjoyed a period of integration, and later stepped back in line. 
see (27) vs. (41), and in those cases where the conjunction is not fully grammaticalised, as in (39)-(40).

(41) Non-integration, due to special semantics, C.Q. “assertive emphasis” (“MARKed focus”, “contrastive stress”) (König and Auwera 1988: 124-125) Hoewel ik Fred niet verdragen kan, haten doe ik hem although I Fred not stand can hate do I him ook niet.

also not

'Although I can't stand Fred, I don't actually hate him.'

In sum, as the tendency for subordinate clauses to get integrated progresses, the semiotic value of main clause inversion risks to break down, as eventually all subordinate clauses may succumb to the integrated construal. This is not happening, though. Thanks to degeneracy in the grammatical system, language users have different cues to assess the semantic level of the subordinate clause.

\section{Conclusions}

What do the case studies on experiencer predicates and subordination in section 3 tell us about the maintenance of the horizontal relations in constructional networks? Overall, languages, as complex adaptive systems, do not rely on a sole strategy to express abstract syntactic-semantic meaning. Horizontal relations between constructions (V1-V2-Vn; NOM-ACC, DAT-GEN ... ; integrated vs. non-integrated subordination) express semantic distinctions that are (partly) expressed by other means as well. In the case of V1 for questions vs. V2 for declaratives, rising intonation is a degenerate way to formulate questions, so that in the absence of V1, clauses can still be interpreted as having interrogative illocutionary force (e.g. $U$ komt toch ook? 'You will come as well, won't you?'). Subordination is expressed by Vn as well as by conjunctions, and occasionally also by V1 (Kom je ook, breng dan een vriend mee 'If you are coming as well, bring a friend'). The semantic level at which the subordinate clauses operates is expressed by inversion in the main clause and by lexical conjunctions. The agency of the experiencer is expressed by case frames, prepositional objects, applicative morphology and voice-based distinctions. This phenomenon, whereby structurally different elements can express the same function is called "degeneracy", with a technical term from evolutionary biology.

Crucially, degeneracy differs from redundancy in that the different strategies are not fully interchangeable and play a role elsewhere in the system as well. Take for instance the use of the (static) passive with experience predicates: it is 
not the case that the static passive's only function in Dutch is to express a lower degree of experiencer agency. It is at work in other parts of the grammar as well. The same goes for V1: initial position of the verb can be used to express interrogative illocutionary force, but it can be used for other things as well, such as the expression of conditionals, exclamatives etc. Rather than a one-to-one relationship between form and meaning, or a many-to-one relationship between form and meaning, degeneracy mostly consists of many-to-many relationships between form and meaning. This has implications for diachrony: form-function change seldom consists of "renewal" so that the loss of a grammatical strategy is compensated for by the development of something new. Neither does it consist of the loss of one of several redundant strategies. Rather, form-function changes involve strengthening of already available resources with extension to new domains when a subsystem comes under pressure. This can be visualised as in Figure 12, representing a hypothetical degenerate system in which the full lines stand for strong links and the dashed lines stand for weak links. As is clear from the figure, the loss of forms does not entail loss of functions, even in the case that no new forms are introduced. The only visible change in the forms is a strengthening of formerly weak links. Diachronic degeneracy is in line with the basic tenets of Construction Grammar that grammar, as part of the Construction, is a complex network of constructions.

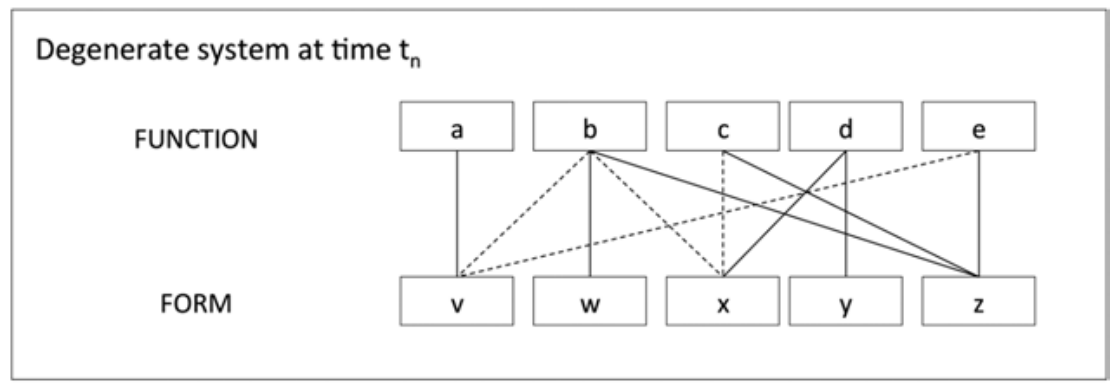

\section{Degenerate system at time $t_{n+1}$}

FUNCTION

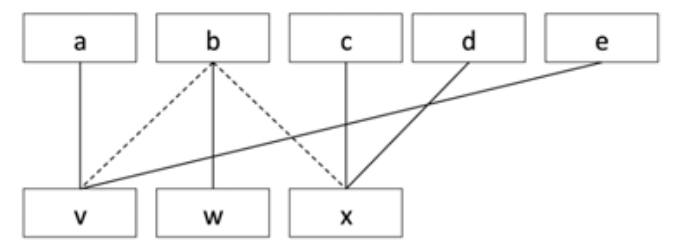

Figure 12: Diachronic form-function change in degenerate systems 
In this article, I have looked at two cases studies: the argument realisation of experiencer predicates and the semantic level of subordinate clauses in Dutch. In both cases, there are several indications that we need a network view as in Figure 12 to understand what is going on. A tentative visualisation is given in Figures 13 and 14, respectively. ${ }^{31}$ With regard to the expression of the agentivity of the experiencer in Figure 13, there is a loss of one of the formal strategies (c.q. case), leading to a strengthening of other strategies, such as voice-based alternations, the use of prefixes having to do with Aktionsart etc. With regard to the expression of clause relations in Figure 14, there is no loss of formal strategies, but the link between form and function shifts through time: V2 becomes stronger as a marker of main clauses (vs. subordinate clauses), which leads to a further integration of subordinate clauses. This weakens the capacity of V2 in main clauses to serve as a cue for the semantic level of attachment of subordinate clauses. This in turn leads to a stronger link between conjunctions and the semantic level of the attachment of subordinate clauses.

\section{Expression of verbal syntax and semantics in Middle Dutch}

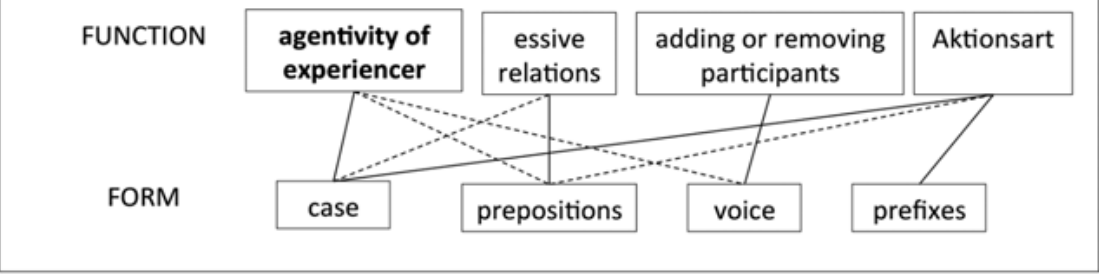

\section{Expression of verbal syntax and semantics in Modern Dutch}

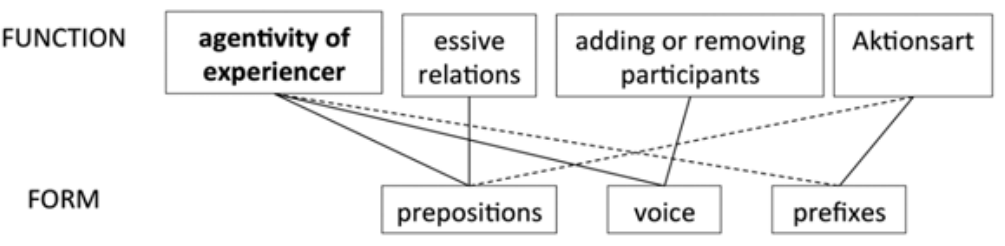

Figure 13: Diachronic degeneracy in the argument realisation of experiencer predicates

31 The details are of lesser importance. In Figure 13 the crucial issue is that the "agentivity of experiencer" box (internally made up of a set of horizontally related constructions - not visualised here) is degenerately controlled in both stages of Dutch. The precise relationships between the other forms and the other functions requires additional study. The same goes for Figure 14, mutatis mutandis. 


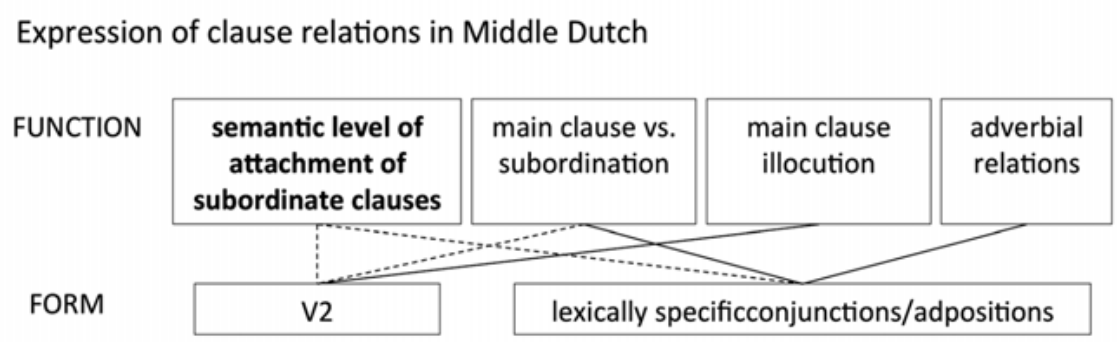

\section{Expression of clause relations in Present-day Dutch}

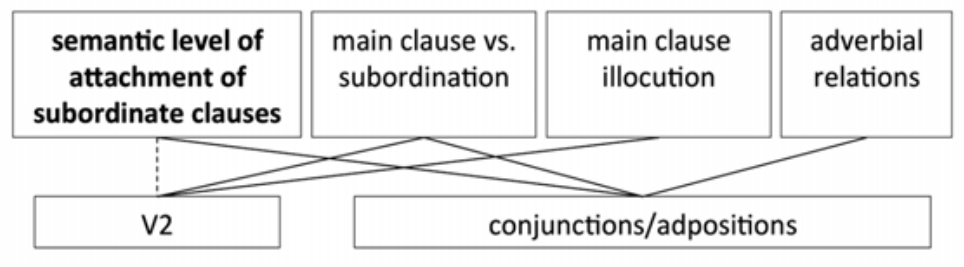

Figure 14: Diachronic degeneracy in the expression of clause relations

\section{Corpora used}

INL38: see Kruyt, J. and M. Dutilh 1997 A 38 million words Dutch text corpus and its users. Lexikos 7: 229-244.

KLASLIT: Klassieke literatuur; Nederlandse letterkunde van de Middeleeuwen tot en met de Tachtigers [Classical literature; Dutch literature from the Middle Ages until the Eightiers] 1999 Cd-rom. Utrecht: Spectrum Electronic Publishing.

LITEROM, see http: //www.knipselkranten.nl/literom. For this corpus study, all material available for the period 2001-2004 was excerpted.

MNW: Middelnederlandsch woordenboek [Middle Dutch Dictionary] 1998 's-Gravenhage: Sdu. Cd-rom version of Eelco Verwijs and Jakob Verdam 1885-1952 Middelnederlandsch woordenboek [Middle Dutch Dictionary]. 's-Gravenhage: Nijhoff.

WNT: Woordenboek der Nederlandsche taal [Dictionary of the Dutch Language] 2003 'sGravenhage: Sdu. Cd-rom version of Matthias de Vries and Lammert te Winkel 18821998 Woordenboek der Nederlandsche taal [Dictionary of the Dutch Language]. 's-Gravenhage: Nijhoff. 


\section{References}

Allen, Cynthia. 1995. Case Marking and Reanalysis: Grammatical Relations from Old to Early Modern English. Oxford: Oxford University Press.

Auwera, Johan van der. 1986. Conditionals and speech acts. In: Elizabeth C. Traugott, Alice Ter Meulen, Judith Snitzer Reilly and Charles A. Ferguson (eds.), On Conditionals, 197-214. Cambridge: Cambridge University Press.

Bardðal, Jóhanna and Thórhallur Eythórsson. 2012. "Hungering and lusting for women and fleshly delicacies": Reconstructing grammatical relations for Proto-Germanic. Transactions of the Philological Society 110: 363-393.

Beckner, Clay, Richard Blythe, Joan Bybee, Morten H. Christiansen, William Croft, Nick C. Ellis, John Holland, Jinyun Ke, Diane Larsen-Freeman and Tom Schoenemann. 2009. Language is a complex adaptive system: position paper. Language Learning 59: 1-26.

Bergen, Benjamin and Nancy Chang. 2013. Embodied Construction Grammar. In: Thomas Hoffmann and Graeme Trousdale (eds.), The Oxford handbook of Construction Grammar, 168190. Oxford: Oxford University Press.

Bolinger, Dwight L. 1980. Language, the Loaded Weapon: The Use and Abuse of Language Today. London: Longman.

Booij, Geert. 2010. Construction Morphology. Oxford: Oxford University Press.

Burridge, Kate. 1993. Syntactic change in Germanic: Aspects of Language Change in Germanic with Particular Reference to Middle Dutch. Amsterdam/Philadelphia: John Benjamins.

Bybee, Joan. 2010. Language, Usage, and Cognition. Cambridge: Cambridge University Press.

Bybee, Joan and Clay Beckner. 2010. Usage-based theory. In: Bernd Heine and Heiko Narrog (eds.), The Oxford Handbook of Linguistic Analysis, 827-855. Oxford: Oxford University Press.

Cinque, Guglielmo. 1999. Adverbs and Functional Heads: A Cross-Linguistic Perspective. Oxford: Oxford University Press.

Cristofaro, Sonia. 2003. Subordination. Oxford: Oxford University Press.

Croft, William. 2000. Explaining Language Change: An Evolutionary Approach. Harlow: Longman.

Croft, William. 2001. Radical Construction Grammar: Syntactic theory in typological perspective. Oxford: Oxford University Press.

Croft, William and D. Alan Cruse. 2004. Cognitive Linguistics. Cambridge: Cambridge University Press.

Davison, Alice. 1981. Markers of derived illocutionary force and paradoxes of speech act modifiers. Cahiers de Linguistique Française 2: 47-73.

Dowty David R. 1991. Thematic proto-roles and argument selection. Language 67: 547-619.

Edelman, Gerald M. and Joseph A. Gally. 2001. Degeneracy and complexity in biological systems. Proceedings of the National Academy of Sciences 98: 13763-13768.

Evans, Vyvyan. 2007. A Glossary of Cognitive Linguistics. Edinburgh: Edinburgh University Press.

Eythórsson, Thórhallur and Jóhanna Bardðal. 2005. Oblique subjects: a common Germanic inheritance. Language 81: 824-881.

Foley, William A. and Richard D. Van Valin. 1984. Functional Syntax and Universal Grammar. Cambridge: Cambridge University Press.

Goldberg, Adele E. 1995. Constructions: A Construction Grammar Approach to Argument Structure. Chicago: University of Chicago Press. 
Goldberg, Adele E. 1996. Making one's way through the data. In: Masayoshi Shibatani and Sandra Thompson (eds.), Grammatical Constructions: Their Form and Meaning, 27-54. Oxford: Oxford University Press.

Goldberg, Adele E. 2006. Constructions at Work: The Nature of Generalization in Language. Oxford: Oxford University Press.

Goldberg, Adele and Alex Del Giudice. 2005. Subject-auxiliary inversion: A natural category. The Linguistic Review 22: 411-428.

Grimm, Scott. 2011. Semantics of case. Morphology 21: 515-544.

Haeseryn, Walter, Kirsten Romijn, Guido Geerts, Jaap de Rooij and Maarten C. van den Toorn. 1997 Algemene Nederlandse Spraakkunst [General Dutch Grammar], 2nd edition. Groningen/ Antwerpen: Martinus Nijhoff/Wolters Plantijn.

Haspelmath, Martin. 1998. Does grammaticalization need reanalysis? Studies in Language 22: 315-351.

Hengeveld, Kees. 1989. Layers and operators in Functional Grammar. Journal of Linguistics 25: 127-157.

Hengeveld, Kees. 1998. Adverbial clauses in the languages of Europe. In: Johan van der Auwera (ed.), Adverbial Constructions in the Languages of Europe, 335-419. Berlin/New York: Mouton de Gruyter.

Hengeveld, Kees. 2004. Illocution, mood, and modality. In: Geert Booij, Christian Lehmann, Joachim Mugdan and Stavros Skopetea (eds.), Morphology. An International Handbook on Inflection and Word-Formation, vol. 2, 1190-1201. Berlin/New York: Mouton de Gruyter.

Holland John. 1992. Complex adaptive systems. Daedalus 121: 17-30.

Hopper, Paul J. 1975. The Syntax of the Simple Sentence in Proto-Germanic. The Hague: Mouton.

Hopper, Paul J. and Elizabeth C. Traugott. 2003. Grammaticalization, 2nd edition. Cambridge: Cambridge University Press.

Horst, Johannes M. van der. 1981. Onderschikking en de plaats van de persoonsvorm in het Middelnederlands [Subordination and the position of the finite verb in Middle Dutch]. Tijdschrift voor Nederlandse Taal- en Letterkunde 97: 161-184.

Horst, Johannes M. van der. 1984. Over vorm en inhoud van bijzinnen [On form and content of subordinate clauses]. In: D.M. Bakker et al. (eds.), Vorm en funktie in tekst en taal: Bundel opstellen verschenen ter gelegenheid van de voltooiing van het honderdste deel van het Tijdschrift voor Nederlandse Taal- en Letterkunde [Form and Function in Text and Language: Essays Appearing on the Occasion of the Completion of the Hundredth Issue of Tijdschrift voor Nederlandse Taal- en Letterkunde], 154-179. Leiden: Brill.

Horst, Johannes M. van der. 1995. Analytische Taalkunde [Analytic Linguistics]. Groningen: Nijhoff.

Horst, Johannes M. van der. 2008. Geschiedenis van de Nederlandse syntaxis [History of the Syntax of Dutch]. Leuven: Leuven University Press.

Huffman, Alan. 2001. The linguistics of William Diver and the Columbia School. Word 52: 2968.

Israel, Michael. 1996. The way constructions grow. In: Adele E. Goldberg (ed.), Conceptual Structure, Discourse and Language, 217-230. Stanford: CSLI.

Jurafsky, Daniel. 1992. An on-line computational model of human sentence interpretation: A theory of the representation and use of linguistic knowledge. Ph.D. dissertation, Computer Science department, University of California at Berkeley.

König, Ekkehard and Johan van der Auwera. 1988. Clause integration in German and Dutch conditional, concessive conditional, and concessive clauses. In: John Haiman and Sandra 
Thompson (eds.), Clause Linking in Grammar and Discourse, 101-133. Amsterdam/ Philadelphia: John Benjamins.

Lakoff, George. 1977. Linguistic gestalts. Chicago Linguistics Society 13: 236-287.

Lehmann, Christian. 1988. Towards a typology of clause linkage. In: John Haiman and Sandra Thompson (eds.), Clause Combining in Grammar and Discourse, 181-225. Amsterdam/ Philadelphia: John Benjamins.

Levin, Beth and Malka Rappaport Hovav. 2005. Argument Realization. Cambridge: Cambridge University Press.

Levin, Magnus. 2009. The formation of the preterite and the past participle. In: Günter Rohdenburg and Julia Schlüter (eds.), One Language, Two Grammars? Differences between British and American English, 60-85. Cambridge: Cambridge University Press.

Michaelis, Laura A. 2009. Sign-Based Construction Grammar. In: Bernd Heine and Heiko Narrog (eds.), The Oxford handbook of Linguistic Analysis, 155-176. Oxford: Oxford University Press.

Mufwene, Salikoko S. 2008. Language Evolution: Contact, Competition and Change. London: Continuum.

Næss, Åshild. 2007. Prototypical Transitivity. Amsterdam/Philadelphia: John Benjamins.

Pagel, Mark. 2007. What is the latest theory of why humans lost their body hair? Why are we the only hairless primate? <http://www.scientificamerican.com/article.cfm?id=latest-theoryhuman-body-hair>.

Ritt, Nikolaus. 2004. Selfish Sounds: A Darwinian Approach to Language Change. Cambridge: Cambridge University Press.

Rosenbach, Anette. 2008. Language change as cultural evolution: Evolutionary approaches to language change. In: Regine Eckardt, Gerhard Jäger and Tonjes Veenstra (eds.), Variation, Selection, Development: Probing the Evolutionary Model of Language Change, 23-72. Berlin/New York: Mouton de Gruyter.

Siewierska, Anna. 2004. Person. Cambridge: Cambridge University Press.

Smessaert, Hans, Bert Cornillie, Dagmar Divjak and Karel Van den Eynde. 2005. Degrees of clause integration: From endotactic to exotactic subordination in Dutch. Linguistics 43: 471-529.

Steels, Luc. 2000. Language as a complex adaptive system. In: M. Schoenauer, K. Deb, G. Rudolph, X. Yao, E. Lutton, J.J Merelo and H.-P. Schwefel (eds.), Proceedings of the 6th international conference on parallel problem solving from nature, 17-26. Berlin: Springer.

Steels, Luc. 2011a. Modeling the cultural evolution of language. Physics of Life Review 8: 339356.

Steels, Luc. 2011b. A first encounter with Fluid Construction Grammar. In: Luc Steels (ed.), Design patterns in Fluid Construction Grammar, 31-68. Amsterdam/Philadelphia: John Benjamins.

Sweetser, Eve. 1990. From Etymology to Pragmatics: Metaphorical and Cultural Aspects of Semantic Structure. Cambridge: Cambridge University Press.

Taylor, John R. 2004. The ecology of constructions . In: Günter Radden and Klaus-Uwe Panther (eds.), Studies in Linguistic Motivation, 49-73. Berlin: Mouton de Gruyter.

Trousdale, Graeme. 2008. Words and constructions in grammaticalization: The end of the English Impersonal Construction. In: Donka Minkova and Susan Fizmaurice (eds.), Empirical and Analytical Advances in the Study of English Language Change, 301-326. Berlin/New York: Mouton de Gruyter. 
Trousdale, Graeme. 2010. Issues in constructional approaches to grammaticalization. In: Ekaterina Stathi, Elke Gehweiler and Ekkehard König (eds.), Grammaticalization: Current Views and Issues, 51-71. Amsterdam/Philadelphia: John Benjamins.

Velde, Freek van de. 2004. De Middelnederlandse onpersoonlijke constructie en haar grammaticale concurrenten: Semantische motivering van de argumentstructuur [The Middle Dutch Impersonal Construction and its grammatical competitors: The semantic motivation of argument structure]. Nederlandse Taalkunde 9: 48-76.

Velde, Freek van de. 2009. De nominale constituent: Structuur en geschiedenis [The Noun Phrase. Structure and History]. Leuven: Leuven University Press.

Verhagen, Arie. 2003. Hoe het Nederlands zich een eigen weg baant: Vergelijkende en historische observaties vanuit een constructie-perspectief [How Dutch creates itself a path. Comparative and historical observations from a constructionist perspective]. Nederlandse Taalkunde 8: 328-346.

Verstraete, Jean-Christophe. 2003. Preverbal positions in three Germanic languages: The role of scope as a functional principle. Languages in contrast 4: 105-136.

Weerman, Fred. 1988. Moet kunnen: Middelnederlandse zinnen zonder subject [Must can: Middle Dutch sentences without a subject]. De Nieuwe Taalgids 81: 289-310.

Weijnen, Antonius. 1971. Schets van de Geschiedenis van de Nederlandse Syntaxis [Contours of the History of the Syntax of Dutch]. Assen: Van Gorcum.

Whitacre, James and Axel Bender. 2010. Degeneracy: A design principle for achieving robustness and evolvability. Journal of Theoretical Biology 263: 143-153.

Zwart, Jan-Wouter. 2011. The Syntax of Dutch. Cambridge: Cambridge University Press. 
Brought to you by | Humboldt-Universität zu Berlin Authenticated

Download Date | 6/6/16 3:47 PM 